\title{
NIOBIUM AS A POTENTIOMETRIC SENSOR IN REDOX TITRATIONS WITH AND WITHOUT PASSIVATION BY AMMONIUM MOLYBDATE.
}

Claudete J. Valduga, Eunice Valduga, Martha Adaime and Nádia Viaro 1

Chemistry Department, Federal University of Santa Maria

Santa Maria - RS - Brazil - 97119-900

\begin{abstract}
ARSTRACT
The $p_{t}$ indicator electrode has been commonly used for redox potentiometric titrations. In this work the $\mathrm{Nb}$ indicator electrode is suggested as an alternative for the $P t$ indicator electrode for the redox potentiometric titrations of the system $\mathrm{Fe}(\mathrm{II}) / \mathrm{K}_{2} \mathrm{Cr}_{2} \mathrm{O} 7$. The utilization of proposed electrode has been studied with and without passivation. The passivation is made by electrode immersion in oxidising anodic inhibitor of $\mathrm{NH}_{4} \mathrm{MOO}_{4}$. The result was an observed increase of the potentiometric leap from $30 \mathrm{mV}$ to $60 \mathrm{mV}$, allowing a better visualization of the equivalence point. The same equivalence point was observed with the conventional and proposed electrode. With the $\mathrm{Nb}$ electrode an inverse potentiometric leap was also obtained.
\end{abstract}

\section{RESUMO}

O eletrodo indicador de platina tem sido usado nas titulações potenciométricas de oxi-redução convencionalmente. Neste trabalho, o eletrodo indicador de nióbio é considerado como uma alternativa ao eletrodo indicador de platina nas titulações potenciométricas de oxiredução para o sistema $\mathrm{Fe}(\mathrm{II}) / \mathrm{K}_{2} \mathrm{Cr}_{2} \mathrm{O}_{4}$. A utilização do eletrodo foi estudada com e sem passivação. A passivação foi feita com a imersão do eletrodo num inibidor oxidante anódico de $\mathrm{NH}_{4} \mathrm{MoO}_{4}$. Como consequência ocorreu um aumento do salto potenciométrico de $30 \mathrm{mV}$ para $60 \mathrm{mV}$ (ECS), permitindo uma melhor visualização do ponto de equivalência. Foi observado o mesmo ponto de equivalência para o eletrodo proposto em relação ao convencional. Além disso, com o eletrodo de nióbio foi obtido um salto potenciométrico invertido.

Keywords: potentiometric sensor; redox titrations; niobium; passivation; ammonium molybdate

Present Address: UFSM (campus), caixa postal 5051, Santa Maria 97119-911, RS-Brazil. 


\section{INTRODUCTION}

The indicator electrodes used in potentiometric titrations depend on the type of reaction that is being investigated. In an acid-base titration it may be a hydrogen electrode or any other electrode that responds to hydrogen ions. The equivalence point of the reaction is revealed by a sudden change of potential in the e.m.f. curve vs the volume of the titrant solution.

Many pure metals are resistant to corrosion and have the common characteristic of forming oxides very adherent to the surface that repress the corrosion and are suitable as proton sensors 1 .

The metal-oxides $\mathrm{xH}_{2} \mathrm{O}$ indicator electrodes have been used as sensors because of their low price and easy handling.

Some metals, such as $\mathrm{Ti}, \mathrm{Ni}, \mathrm{Ta}$ and alloys such as chromium-cobalt and stainless steel tend to become passive due to the formation of a thin, adherent layer of oxide or another compound that proctects them from oxidation ${ }^{2}$.

The sensibility of metal-oxide $\mathrm{xH}_{2} \mathrm{O}$ electrodes in redox titration was studied by Sayed ${ }^{3}$. Redox titrations were made and appreciable potential leaps were observed in the equivalence point.

The $\mathrm{Nb}$ is covered by a $\mathrm{Nb}_{2} \mathrm{O}_{5}$ film that can be dissolved by fusion with hydroxide but is not attacked by the hydrogen ion ${ }^{4}$.

Chromium-Nickel alloys, used as potentiometric sensor in redox titrations, show well determined potentiometric leaps, and usually in the same potential range of platinum electrodes. These potentiometric leaps are usually $50 \%$ of the value of the leaps obtained when platinum electrode are used 5 .

The first studies carried out to verify the response of metallic-oxide films used hastelloy alloys and have shown that the film can respond to protons in solution. Systematic studies in acid-base reactions and the Nernst type behavior extends to the range of $\mathrm{pH} 1,0$ to $\mathrm{pH} 13,0^{6}$.

In this work, $\mathrm{Nb}$ was used as indicator electrode in redox potentiometric titration for the system $\mathrm{Fe}(\mathrm{II}) / \mathrm{K}_{2} \mathrm{Cr}_{2} \mathrm{O}_{7}$. The passivation was made to increase the potentiometric leap.

\section{MATERIALS AND METHODS}

Potentiometric titrations of $0,01 \mathrm{~N} \mathrm{FeSO}_{4} \cdot 7 \mathrm{H}_{2} \mathrm{O}$ (in $\mathrm{H}_{2} \mathrm{SO}_{4}$ solution) with $0,1 \mathrm{~N} \mathrm{~K}_{2} \mathrm{Cr}_{2} \mathrm{O}_{7}$ solution were done, with stirring at room temperature using the calomel electrode as reference and a $\mathrm{Nb}$ electrode as indicator, instead of the $\mathrm{Pt}$ electrode. The $\mathrm{Nb}$ electrode was sanded with granulometry $280,320,400$ and 600 a paper and then polished with $\mathrm{Al}_{2} \mathrm{O}_{3}$.

In some cases, the $\mathrm{Nb}$ electrodes were treated chemically and the passivation was achieved by immersion in $0,01 \mathrm{~N} \mathrm{NH}_{4} \mathrm{MoO}_{4}$ solution for thirty minutes and for one hour. 
The titrations were conducted at $25 \pm 1^{\circ} \mathrm{C}$, with a PW 9409 Phillips potentiometer using a Shott Mainz B281 calomel electrode of simple junction, as reference. In order to achieve a better resolution a 274 microburete Methrohm was used. A 702 Fisaton magnetic stirrer, was used to ensure adequate mixing.

\section{RESULTS AND DISCUSSION}

Figures 2 and 3 show that the equivalence points in the titrations coincide exactly with that verified when the Pt electrode is used (Figure 1 ), although the potential leap is reversed and smaller.

The $\mathrm{Nb}$ electrode passivated by immersion in oxidizing anodic inhibitor solution of $\mathrm{NH}_{4} \mathrm{MoO}_{4}$ for thirty minutes and one hour presented a potentiometric leap of about $60 \mathrm{mV}$, that is twice that observed without passivation in the $\mathrm{Fe}(\mathrm{II})$ titration by $\mathrm{K}_{2} \mathrm{Cr}_{2} \mathrm{O}_{7}(30 \mathrm{mV})$. The passivated electrode allows a better detection of the equivalence point.

When the $\mathrm{Nb}$ is exposed to the air, it has the characteristic of formation of a film mainly of $\mathrm{Nb}_{2} \mathrm{O}_{5}$.

The oxidizing anodic inhibitor of $\mathrm{NH}_{4} \mathrm{MoO}_{4}$, probably makes this layer thicker and the redox potential becomes higher than the original one.

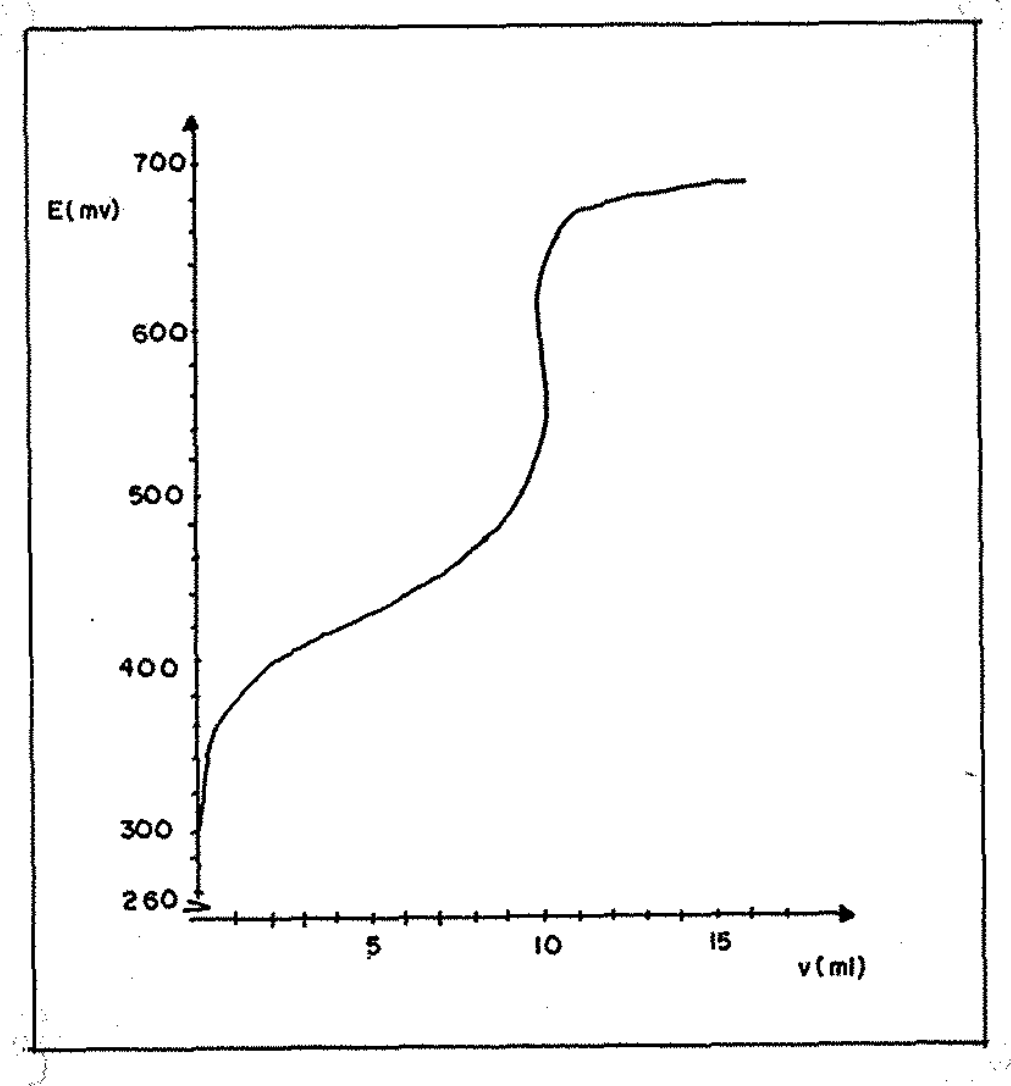

Figure 1. Titration curve using $\mathrm{Pt}$ indicator electrode for the system $\mathrm{Fe}$ (II) $/ \mathrm{Cr}$ (VI). 


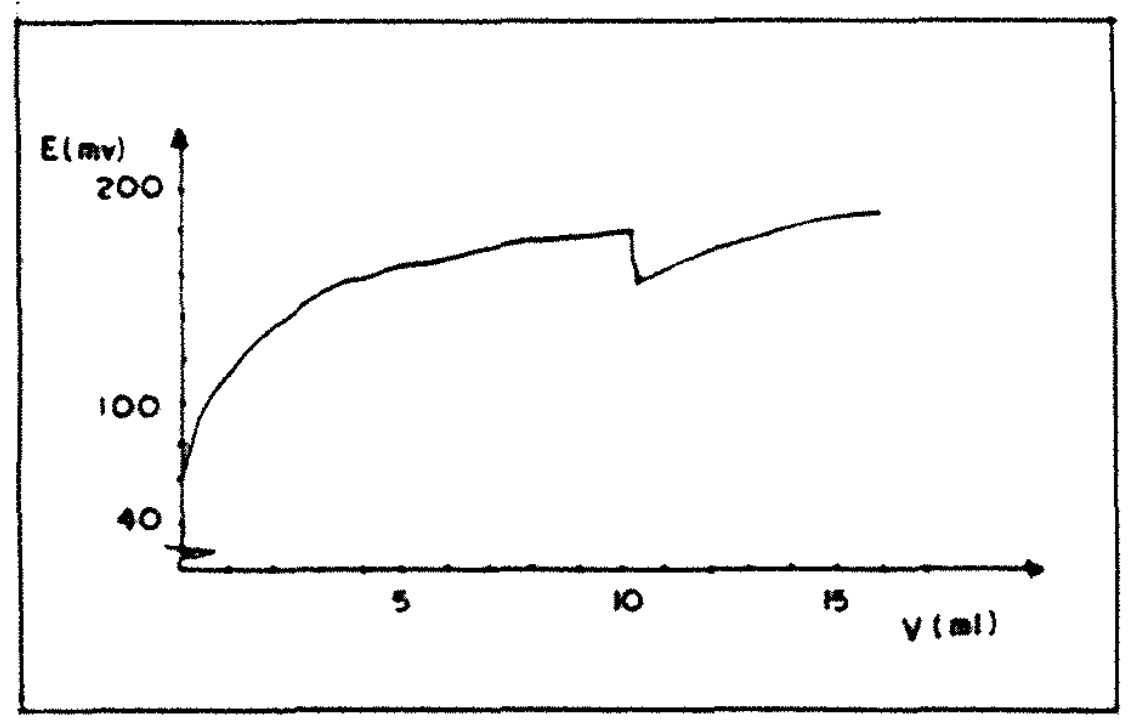

Figure 2. Titration curve using $\mathrm{Nb}$ indicator electrode without passivation for the system $\mathrm{Fe}(\mathrm{II}) / \mathrm{Cr}(\mathrm{VI})$.

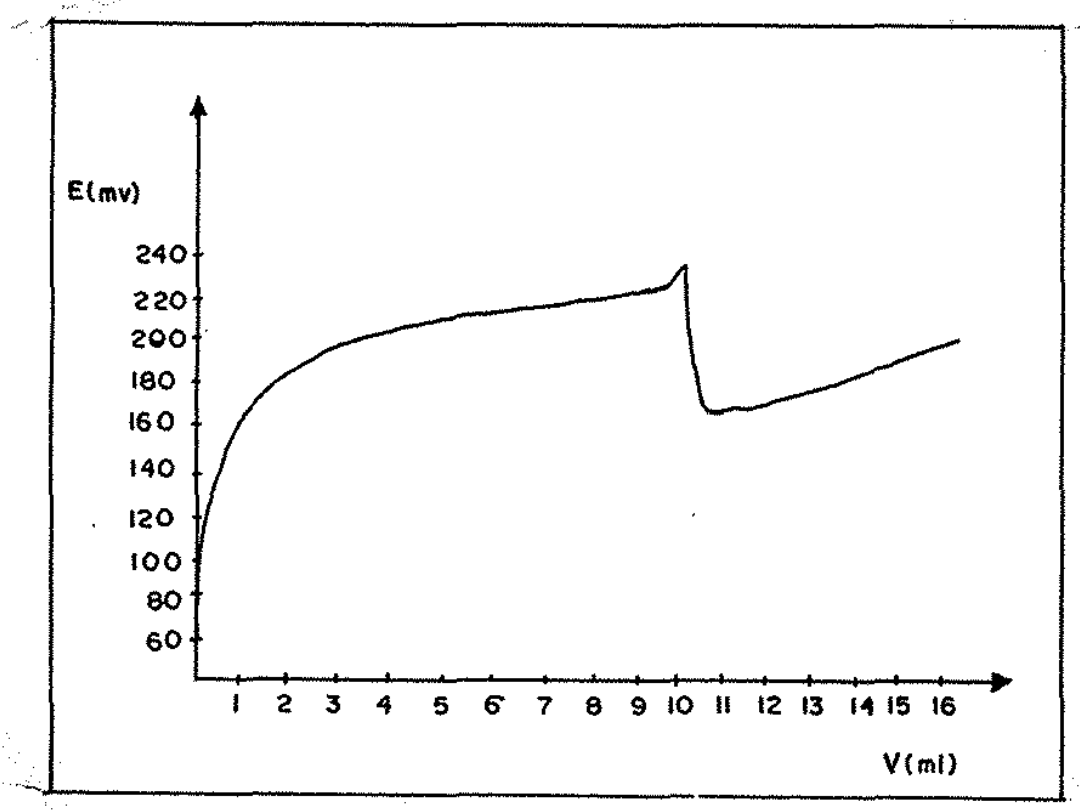

Figure 3. Titration curve using $\mathrm{Nb}$ indicator electrode with passivation for the system $\mathrm{Fe}$ (II)/Cr (VI). 
C.J. Valduga, E. Valduga, M. Adaime \& N. Viaro,

\section{REFERENCES}

1. M. Ashrof-Chorassani and R.D. Braum, Corrosion - NACE, 43, $32(1987)$.

2. J. Breme, "Titanium and Titanium Alloys the Biomaterial of Preference" (Plenary Lecture), 6th International Conference on Titanium, Cannes (1988).

3. S.M. Sayed, J. Chem., 21, 431 (1978).

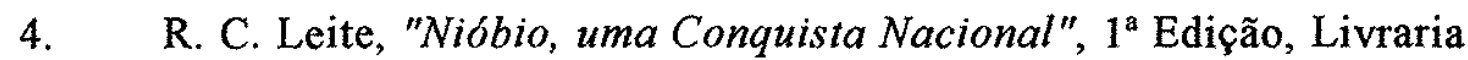
Duas Cidades Ltda, São Paulo, S.P. , 1988

5. A.C. Magalhães, M.D. Capelato, Uso de Ligas Ni-Cr como Sensor Potenciométrico em Titulações Redox, Química Nova 14 (4), 37 (1991).

6. K. Nomura, Y.Ujhara, Anal. Chem., 60, 2564 (1988). 